\title{
The geographical and institutional proximity of research collaboration
}

\author{
Roderik Ponds ${ }^{1,2}$, Frank van Oort ${ }^{1,2}$, Koen Frenken ${ }^{2}$ \\ ${ }^{1}$ Netherlands Institute for Spatial Research, P.O. Box 30314, 2596 BK, The Hague, \\ The Netherlands (e-mail: ponds@rpb.nl; oort@rpb.nl) \\ ${ }^{2}$ Urban and Regional research centre Utrecht, Faculty of Geosciences, Utrecht University, P.O. Box \\ 80115, 3508 TC, Utrecht, The Netherlands (e-mail: k.frenken@geo.uu.nl)
}

Received: 28 November 2006 / Accepted: 03 April 2007

\begin{abstract}
Collaboration and the exchange of knowledge are supposedly made easier by geographical proximity because of the tacit character of knowledge. Recently a number of scholars' criticised this view on geographical proximity as being oversimplified and argued that the precise role of geographical proximity for knowledge exchange and collaboration still remains unclear. This paper analyses the role of geographical proximity for collaborative scientific research in sciencebased technologies between universities, companies and governmental research institutes. We test the hypothesis that the collaboration between different kinds of organisations is more geographically localised than collaboration between organisations that are similar due to institutional proximity. Using data on co-publications, collaborations patterns are analysed and the hypothesis is confirmed.
\end{abstract}

\section{JEL classification: $\mathrm{R} 12, \mathrm{O} 31$}

Key words: Research collaboration, proximity, knowledge, university-industry collaboration

\section{Introduction}

For many years now, the relationship between scientific research, technological innovation and regional economic development has been an important theme in

* We thank three anonymous reviewers for their useful suggestions on how to improve the paper. We are also grateful to Ron Boschma for helpful comments on an earlier version of this paper. Finally we thank Stephaan Declerck for his help in data handling. 
innovation studies and economic geography. Relevant literature indicates that, particularly in science-based industries, the interaction between research institutes and firms is a crucial factor in innovation processes. A number of scholars have focused on the role of geography in these interaction processes and have found evidence for localised knowledge spillovers from universities and other academic organisations (see amongst others: Jaffe et al. 1993; Varga 1998; Anselin et al. 2000; Acs 2002). It is often assumed that geographical proximity renders collaboration more likely, because the tacit character of knowledge requires face-to-face interaction. Recently however, this line of reasoning has been questioned by several authors (Malmberg and Maskell 2002; Torre and Rallet 2005; Boschma 2005). They suggest that geographical proximity can only have an indirect role, and is neither a prerequisite nor sufficient for successful collaboration. Geographical proximity supposedly plays a more 'subtle and indirect role' (Howells 2002) in positively influencing collaboration and knowledge exchange. Little is known about the role of geographical proximity in scientific collaboration and how this affects the nature and probability of collaboration. Since collaboration in scientific knowledge production has become a central policy issue (Canton et al. 2005), it is surprising that only few researchers have tried to understand the geography of these research collaborations. An important part of research collaboration, especially within applied sciences, takes place between different universities, companies and governmental institutes (Etzkowitz and Leydesdorff 2000). In this context, it has been argued that the regional scale is highly relevant where the differences in institutional contexts are to be overcome (Cooke et al. 1997). In other words, geographical proximity can compensate the lack of institutional proximity. We will test the hypothesis that research collaboration involving different kinds of organisations (companies, academic organisations, governmental research institutes) is more geographically localised than collaboration between similar organisations. To this end, we analyse data on collaboration patterns in eight science-based technologies at different spatial scales for the period 1988-2004.

The following section first elaborates on the relation between proximity and knowledge exchange (section 2). In section 3 the central hypothesis focusing on spatial characteristics of collaboration in scientific knowledge production between various organisations - is embedded in the empirical literature on the subject of science and proximity. Section 4 focuses on data and measurement issues. It explains how the importance of geographical proximity for collaboration in science is measured taking into account institutional proximity by differentiation with the organisation background. Section 5 describes the spatial structure of scientific collaboration in the Netherlands on several spatial scales. In sections 6 and 7 we test the hypothesis that spatial collaboration between academic organisations and non-academic organisations (companies or governmental organisations) is more regionalised than collaboration between academic organisations. A censored tobit regression is applied in order to judge whether or not certain types of collaborations are indeed occurring at different distances (section 6). A further test for the influence of geographical proximity on the intensity of different forms of collaboration 
within the Netherlands is given using a gravity model (section 7). Section 8 concludes.

\section{Geographical proximity and knowledge exchange}

Consensus has grown among economists and economic geographers that knowledge production and knowledge spillovers are, to a great extent, geographically localised (Jaffe et al. 1993; Audretsch and Feldman 1996; Feldman 1999; Van Oort 2004). To test for knowledge spillovers, most scholars apply a knowledge production function approach in order to explain the regional production of patents or innovations as a result of public and private $R \& D$ inputs and a local spillover index. In more than one case, and at different spatial levels, scholars have been able to indicate that such spillovers turn out to be statistically significant, that is, they exert a significant and positive effect on knowledge output as measured by patents or innovations. In particular, the money spent on university research in a region is said to be very beneficial for innovation in that region (Jaffe et al. 1993). Knowledge spillovers from universities and other academic research institutions seem to be spatially bounded, as shown by Jaffe et al. (1993), who found that the large majority of citations for U.S. patents stem from the same state as the one from which the cited patent originated, even when corrected for differences in regional sector distributions.

Geographical proximity is frequently claimed to be beneficial for successful collaboration and knowledge exchange. This is most often explained by the importance of face-to-face contacts for the exchange of tacit knowledge. In many studies this localised interaction is however, only implicitly assumed rather than examined in an explicit manner. A number of authors have theoretically questioned the importance of geographical proximity in itself for collaboration and knowledge exchange (see for example Breschi and Lissoni 2001; Howells 2002; Gertler 2003; Torre and Rallet 2005; Boschma 2005). The main argument is that 'simple' co-location is neither a prerequisite nor a sufficient condition' (Boschma 2005, p. 71) for collaboration. Other forms of proximity may well be at least as important for collaboration and knowledge exchange. For example, different branches of a multinational are considered to be organisationally close and can easily exchange knowledge regardless of the physical distance between them. Scientists can also easily collaborate over long distances due to the common language and incentive structure (publishing). Geographical proximity however, can be very important in a more indirect way by overcoming possible difficulties due to differences in institutional or organisational backgrounds such as in academic-company or academic-governmental collaboration. In these types of collaboration, problems typically arise from conflicts of interest or from differences based on a lack of institutional proximity. For successful collaboration mutual trust is necessary in order to overcome these problems. Geographical proximity can positively influence the building of mutual trust due to frequent interaction and face-to-face contacts. According to Boschma (2005), geographical proximity can compensate for the lack of institutional proximity. And, reversely, institutional proximity facilitates interaction over long geographical distances. 


\section{Science and proximity}

Scientific research collaboration is a growing phenomenon and the proportion of co-publications in the total number of scientific publications has also been steadily increasing (Wagner-Doebler 2001). Several reasons can be distinguished for the growing importance of collaboration which can be seen as the outcome of an increasing division of labour between researchers (Katz and Martin 1997). First of all there seems to be an increase in the number of scientific fields and subfields, many of them being interdisciplinary fields such as biotechnology. As a result, research increasingly depends on the combination of the knowledge and skills of researchers from different subfields. Secondly, the costs of research facilities are increasing rapidly, especially in sciences such as physics or life sciences. Resources are consequently more and more pooled at the regional, national and sometimes international level which forces researchers from different research organisations to collaborate more intensively. Thirdly, and related, is the increasing need for specialisation in those fields where the instrumentation is becoming more and more complex (Gordon 1980). Fourthly, funding in different countries and at the EU level is becoming more and more dependent on the level and intensity of international collaboration, as illustrated by the aim of the EU framework programs to create a 'European research area'.

While internationalisation has received a lot of scholarly attention, this being facilitated by Internet and cheap air travel, only a few scholars have focused on the role of geographical proximity in scientific knowledge production. There are at least two reasons why geography is still important for research collaboration. First of all, collaboration across greater distances remains more costly than collaboration at closer range, despite improved transportation possibilities and the rise of ICT. Some scholars found that geographical proximity is indeed important and does have a positive effect on the intensity and frequency of scientific collaboration (Katz 1994; Liang and Zhu 2002). Secondly, collaboration between academic and non-academic organisations, which is a frequently occurring phenomenon in science-based technologies (Pavitt 1984; DeSolla Price 1984), is assumed to be more localised in space. The increasing importance of non-academic organisations in science is sometimes referred to as the Triple-Helix (Etzkowitz and Leydesdorff 2000).

To understand the impact of geographical proximity in science-based technologies, the differences between science and technology should be taken into account in more detail. Scientific research is fundamentally different from industrial innovation (Dasgupta and David 1994). Gittelman and Kogut (2003, p. 367) state it like this; ". . . the logic of scientific discovery does not adhere to the same logic that governs the development of new technologies". Scientific research and the research for industrial innovation are conducted within different socioeconomic structures.

The major difference lays in the goal of the research and as a consequence the underlying incentive structure (Dasgupta and David 1994; Frenken and Van Oort 2004). The main goal in science, and of scientific publishing, is to add new knowledge to the existing 'stock of knowledge' and to diffuse this new knowledge as widely as possible, whereas industrial research and innovation is concerned 
with ". . . adding to the streams of rents that may be derived from possession of (rights to use) private knowledge" (Dasgupta and David 1994, p. 498). As a result the incentive structures regarding knowledge production in academia and in industry are conflicting: in academia actors want to maximise the diffusion of their knowledge, while companies want to minimise such diffusion.

When universities and companies collaborate in research, the differences in incentive structure and institutional backgrounds give rise to complex arrangements. The complexity of these collaborations renders it generally impossible to encode all contingencies in a contract and consequently, these collaborations have to rely, at least partially, on less formal institutions thereby reducing the risk of opportunism. Therefore, one may argue that, in the case of collaboration between academic and non-academic organisations (such as academic-company relations), geographical proximity may be supportive in establishing successful partnerships between organisations with structurally different institutional backgrounds. Geographical proximity may help to overcome these problems, because of a common interest in exchanging labour, accessing local funds and mutual trust induced by informal contacts and interaction. By contrast, when organisations with the same institutional background collaborate in research, that is when institutional proximity is high as in the case of two universities, successful interaction is less dependent on geographical proximity as collaboration takes place within a common framework of incentives and constraints. Thus, the main hypothesis underlying our study thus holds that research collaborations between organisations with different institutional backgrounds occur more often over short geographical distances than research collaborations between organisations with the same institutional background.

In the following sections, the spatial characteristics of collaboration in scientific knowledge production between various organisations will be analysed. The main goal is to find out what the spatial patterns of different forms of collaboration in scientific knowledge production are. We propose to measure the importance of geographical proximity for collaboration in science, taking into account institutional proximity by distinguishing between the institutional backgrounds of different organisations. Organisations with the same incentive structures are defined as being institutionally close. Cognitive distance is controlled for by focusing exclusively on collaborations within scientific disciplines. Thus, in the following it is assumed that cognitive distance is small.

\section{Data: Co-publications as an indicator for research collaboration}

Co-publications are used as an indicator for collaboration in scientific research. Scientific publications are the most common form of output in scientific research, which implies that collaboration in scientific research will often be reflected in a co-publication. ${ }^{1}$ We use data from Web of Science, a product offered by the

${ }^{1}$ The question remains as to why firms publish (some of) the results of their research in scientific journals. Rosenberg (1990) views publications by firms as 'a ticket of admission to an information 
Institute of Scientific Information (ISI, http://www.isinet.com/). Web of Science contains information on publications in all major journals in the world for 1988 onwards. It covers three databases: the Science Citation Index (SCI) including natural science journals, the Social Science Citation Index (SSCI) including social science journals, and the Arts and Humanities Citation Index (A\&JCI) including journals belonging to the arts and humanities. Using Web of Science, one can construct data on a specific discipline in a relatively straightforward way. Once a list of journals that is representative for the scientific discipline in question is obtained, publications belonging to a discipline can be simply retrieved by using the set of journals as a query. We analysed publications for those disciplines that contributed the most to technological innovation in science-based technologies. The selection of the technologies and the relevant scientific disciplines was based on the analysis of citations from patents to scientific articles by Van Looy et al. (2003). They estimated the science intensity of a technology by comparing the proportion of citations to scientific articles for different technological coherent patent classes. Based on the ISI grouping of journals into sub-disciplines, the relevant scientific fields for each science-based technology were estimated. For a further description of this method of linking science to technology, see Van Looy et al. (2003). Based on their analysis the following technologies are selected: agriculture \& food chemistry, biotechnology, organic fine chemistry, analysis, measurement \& control technology, optics, information technology, semiconductors and telecommunication. Some technologies are more alike in terms of their science base than others are. Based on a comparison of the relevant scientific subfields it is possible to make a distinction between life-sciences based technologies and physical sciences based technologies. Table 1 shows the relevant scientific subfields for each technology grouped into these broad sectors.

Collaboration is defined as the co-occurrence of two or more addresses on a publication. Although collaboration in its essence takes place between people, our focus is on organisations. Addresses attached to the publications refer to institutional affiliations and not to single persons per se. Although individual authors can be distinguished in ISI, it is not possible to link these individuals to organisations since this information is not available when the data is downloaded in a database format. This means that a single-author paper with two or more affiliations is also counted as collaboration whereas a multi-authored paper with one address (i.e. an intra-organisation collaboration) is not regarded as collaboration (see also Katz and Martin 1997). All publications in the relevant scientific subfields for the period 1988-2004 with at least one address in the Netherlands have been retrieved for each of the eight selected technologies. Figure 1 shows the shares of co-publications in the total number of publications for all technologies in every

network' (p. 170). For a firm to learn from external sources, their employees have to collaborate with external actors and to be active in a network of research institutes, universities and other companies. To become a member of these networks, they have to adhere to the social norm of publishing to become part of the scientific community (Cockburn and Henderson 1998). In particular, when firms collaborate with universities or governmental research institutes, publication is likely. Goddard and Isabelle (2006) indicate, for example, that co-publications are the most frequently occurring outcome of research collaboration between French academic organisations and firms. 
Table 1. The relevant science-fields ${ }^{\dagger}$ for technological innovation in the eight selected technologies

\begin{tabular}{|c|c|}
\hline $\begin{array}{l}\text { Agriculture \& food chemistry } \\
(n=40,369)\end{array}$ & $\begin{array}{l}\text { Optics }^{\mathrm{b}} \\
(n=16,499)\end{array}$ \\
\hline $\begin{array}{l}\text { Biochemistry \& Molecular Biology } \\
\text { Plant Sciences } \\
\text { Microbiology } \\
\text { Genetics \& Heredity } \\
\text { Food Science \& Technology } \\
\text { Agriculture Dairy \& Animal Science } \\
\text { Nutrition \& Dietetics }\end{array}$ & $\begin{array}{l}\text { Optics } \\
\text { Electrical \& Electronical Engineering } \\
\text { Applied Physics } \\
\text { Polymer Science }\end{array}$ \\
\hline $\begin{array}{l}\text { Analysis, measure \& control technology } \\
(n=31,175)\end{array}$ & $\begin{array}{l}\text { Organic fine chemistry }{ }^{\mathrm{a}} \\
(n=46,504)\end{array}$ \\
\hline $\begin{array}{l}\text { Biochemistry \& Molecular Biology } \\
\text { Applied Physics } \\
\text { Instruments \& Instrumentation } \\
\text { Electrical \& Electronical Engineering } \\
\text { Immunology } \\
\text { Analytical Chemistry }\end{array}$ & $\begin{array}{l}\text { Biochemistry \& Molecular Biology } \\
\text { Organic Chemistry } \\
\text { Pharmacology \& Pharmacy } \\
\text { Immunology } \\
\text { Genetics \& Heredity } \\
\text { Microbiology }\end{array}$ \\
\hline $\begin{array}{l}\text { Biotechnology }{ }^{\mathrm{a}} \\
(n=43,250)\end{array}$ & $\begin{array}{l}\text { Semiconductors }{ }^{\mathrm{b}} \\
(n=16,289)\end{array}$ \\
\hline $\begin{array}{l}\text { Biochemistry \& Molecular Biology } \\
\text { Microbiology } \\
\text { Genetics \& Heredity } \\
\text { Immunology } \\
\text { Virology } \\
\text { Biophysics } \\
\text { Biotechnology \& Applied Microbiology }\end{array}$ & $\begin{array}{l}\text { Electrical \& Electronical Engineering } \\
\text { Physics Condensed Matters } \\
\text { Crystallography } \\
\text { Applied Physics } \\
\text { Nuclear Science and Technology } \\
\text { Material Science }\end{array}$ \\
\hline $\begin{array}{l}\text { Information technology } \\
(n=8,184)\end{array}$ & $\begin{array}{l}\text { Telecommunication }{ }^{\mathrm{b}} \\
(n=14,158)\end{array}$ \\
\hline $\begin{array}{l}\text { Electrical \& Electronical Engineering } \\
\text { Computer Applications } \\
\text { Computer Cybernetics } \\
\text { Telecommunications } \\
\text { Acoustics }\end{array}$ & $\begin{array}{l}\text { Electrical \& Electronical Engineering } \\
\text { Telecommunications } \\
\text { Optics } \\
\text { Applied Physics } \\
\text { Computer Applications } \\
\text { Computer Cybernetics }\end{array}$ \\
\hline
\end{tabular}

Notes: ${ }^{\dagger}$ As defined by the Institute for Scientific Information (ISI). ${ }^{a}$ Life sciences, ${ }^{b}$ Physical sciences.

year between 1988 en 2004. For all technologies, it becomes clear that collaboration is a growing phenomenon, a finding that is in line with findings of various other authors on collaboration in science (Luukkonen et al. 1992 and 1993; Glänzel 2001; Wagner-Doebler 2001; Wagner and Leydesdorff 2005; Wagner 2005).

Every co-occurrence of two organisations is counted as collaboration. Thus, no distinction is made between collaborations stemming from co-publications 


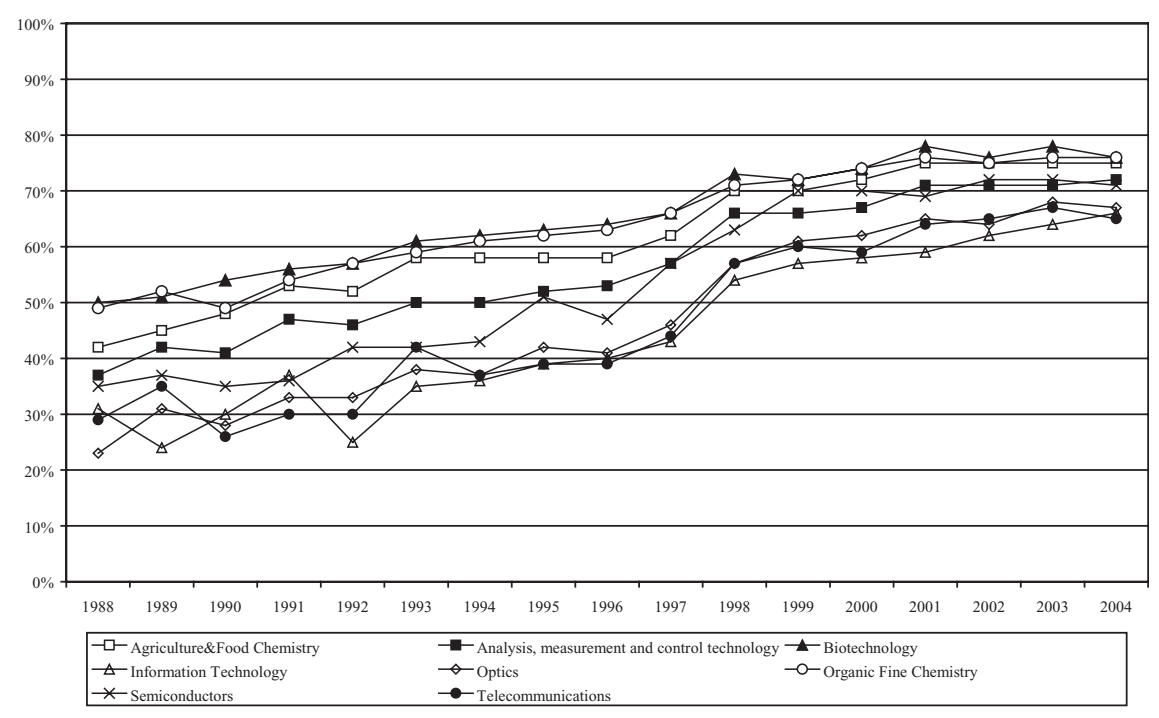

Fig. 1. The share of co-publications in the total number of publications

with two organisations or co-publications with more than two organisations involved. A co-publication with $n$ organisations has $n(n-1) / 2$ collaborations. These collaborations are then aggregated and these collaborations are the unit of analysis in this paper. Over time the number of collaborations is growing in all technologies. This is not only because of the growth of the number of co-publications but also because of the growth of the average number of organisations per co-publication.

\section{Spatial structure of scientific collaboration}

The spatial scale of a collaboration was determined by analysing the addresses of the organisations involved. We aggregated collaborations at the NUTS3 level. This regional classification is based on regional labour markets, which usually consist of a city and its surrounding municipalities. Within the Netherlands there are 40 NUTS3 regions. At the international level a distinction is made between collaboration with EU countries (including Switzerland and Norway), the USA and other countries (labelled international collaborations).

Table 2 shows the importance of the various spatial scales for collaboration in science for the different technologies. Collaboration in science has a clear international focus. The majority of all collaborations is at the international level. The EU countries are by far the most important partners.

Although the phenomenon of international research collaboration is an interesting one, in the remainder of this paper the focus lies on collaboration within the Netherlands. Figures 2 to 9 show the spatial pattern of scientific collaboration in 
Table 2. Importance of various spatial scales for collaboration in science for Dutch organisations

\begin{tabular}{lcccc}
\hline & National & EU & USA & Other countries \\
\hline Agriculture \& food chemistry & 0.28 & 0.42 & 0.16 & 0.13 \\
Analysis, measurement and control technology & 0.23 & 0.45 & 0.17 & 0.15 \\
Biotechnology & 0.30 & 0.41 & 0.17 & 0.12 \\
Information technology & 0.30 & 0.40 & 0.16 & 0.14 \\
Optics & 0.23 & 0.44 & 0.14 & 0.19 \\
Organic fine chemistry & 0.33 & 0.40 & 0.16 & 0.11 \\
Semiconductors & 0.19 & 0.46 & 0.13 & 0.23 \\
Telecommunications & 0.23 & 0.42 & 0.17 & 0.18 \\
\hline
\end{tabular}

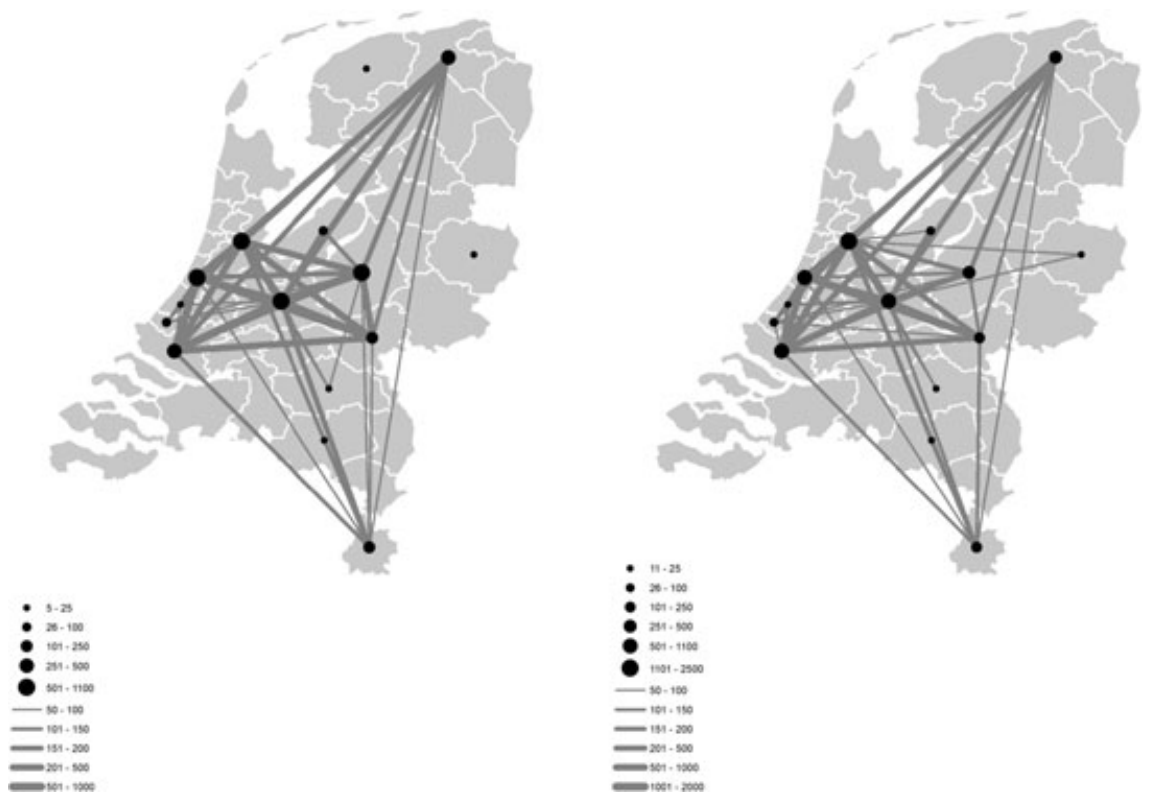

Fig. 2 and 3. Spatial patterns of scientific collaboration in agriculture \& food chemistry and biotechnology

the different technologies within the Netherlands at the NUTS3-level for the period 1988-2004. The thickness of the lines shows the intensity (in terms of the total number of collaborations) of collaboration between two NUTS3 regions and the size of the dot shows the intensity of collaboration within a region.

The spatial patterns of collaboration within the different life-sciences based technologies (Figures 2 to 4 ) are very much alike. To a lesser extent, this is also the case for the different physical science-based technologies (Figures 6 to 9). The earlier made distinction between two broad sectors of life-sciences based and physical sciences-based technologies seems therefore justified. The close resemblance between the spatial structures of related technologies is of course related to the earlier noted similarities in the science base of these technologies. 


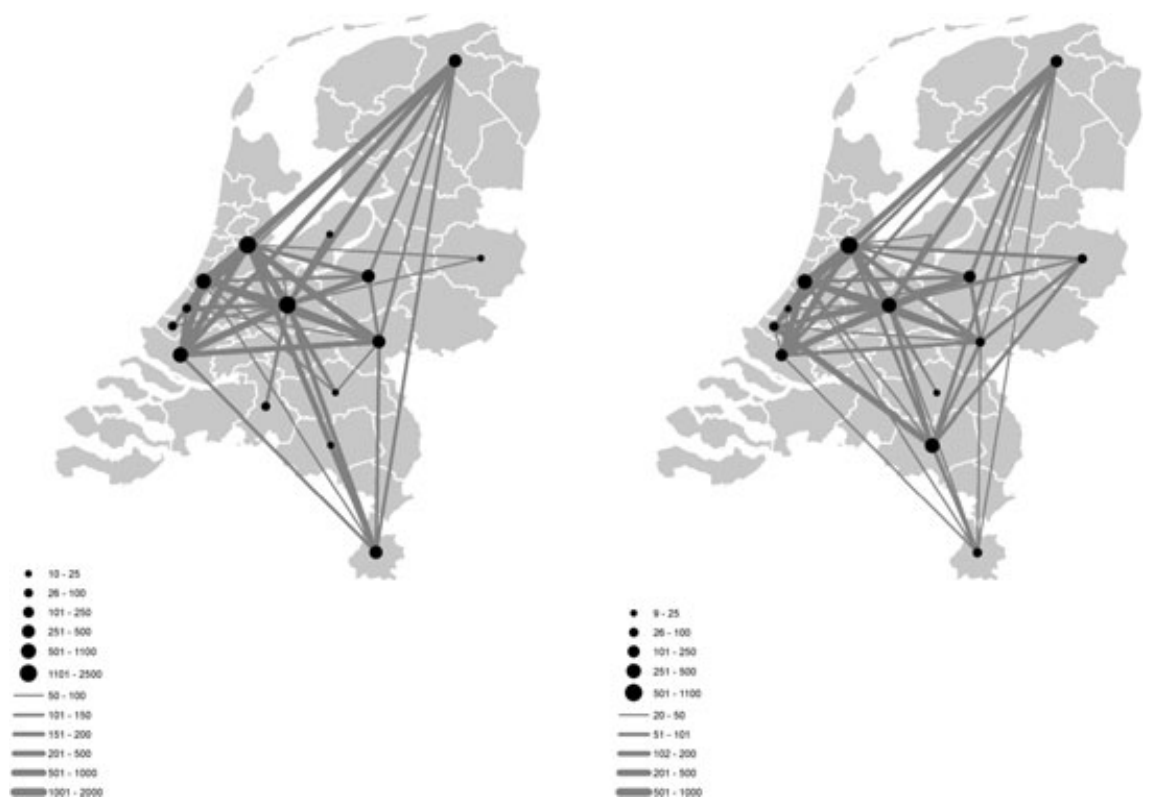

Fig. 4 and 5. Spatial patterns of scientific collaboration in organic fine chemistry and analysis, control $\&$ measurement technology
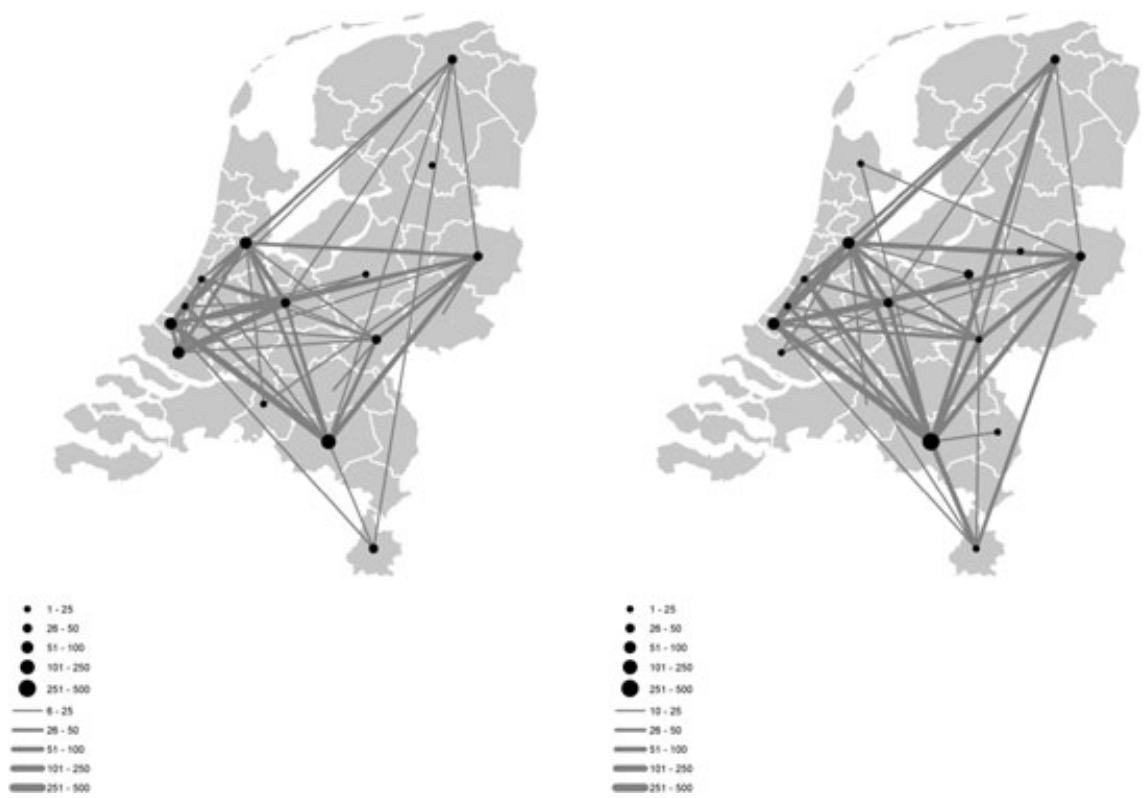

Fig. 6 and 7. Spatial patterns of scientific collaboration in information technology and optics 


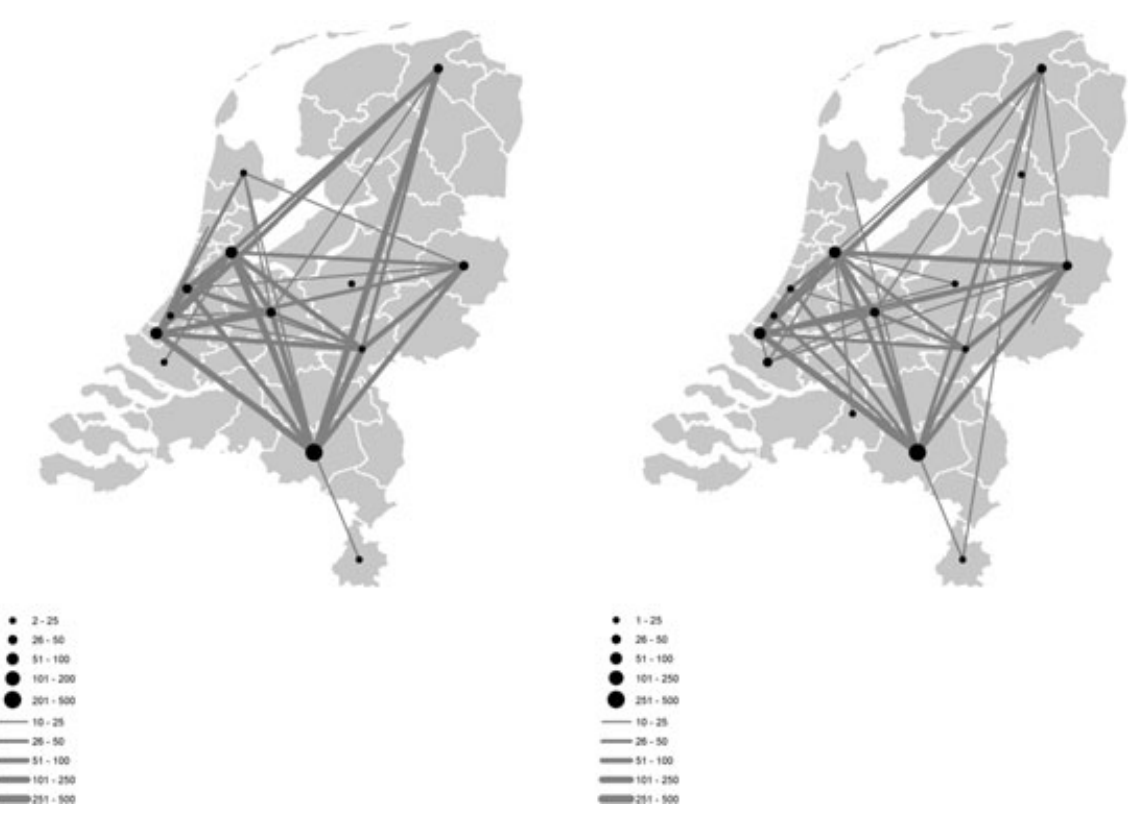

Fig. 8 and 9. Spatial patterns of scientific collaboration in semiconductors and telecommunications

A comparison of the physical science-based technologies with the life-sciences based technologies shows that the spatial structures or collaboration are clearly different, suggesting regional specialisation in related scientific subfields. Collaboration within life sciences like biotechnology take place to a large extent between and within regions in the Western part of the Netherlands like Amsterdam, Leiden and Utrecht, in the economic centre called the Randstad. The spatial structure of collaboration within the different physical sciences-based technologies shows a somewhat different picture. The importance of the South-East Brabant region (around the city of Eindhoven) is apparent and can be traced back to a concentration of (micro-) electronics firms and related organisations clustered around the Dutch electronics multinational Philips and the Eindhoven University of Technology.

In order to analyse whether collaborations between different kinds of organisations have another spatial configuration than those between the same kind of organisations we distinguished three different types of organisations: academic organisations, companies and governmental/non-profit-making organisations. Academic organisations are those organisations whose primary goal is the advance of science - universities and other academic research organisations alike. Many governmental and non-profit-making organisations are additionally engaged in scientific research, but their main goals are often not the advance of science itself but lie merely in the use of the results of this research for society-broad goals. In order to identify the different types of organisations we used an algorithm with a list of abbreviations and words to assign each address to one of three types of organisations. For example organisations with 'univ' in its name were assumed to 


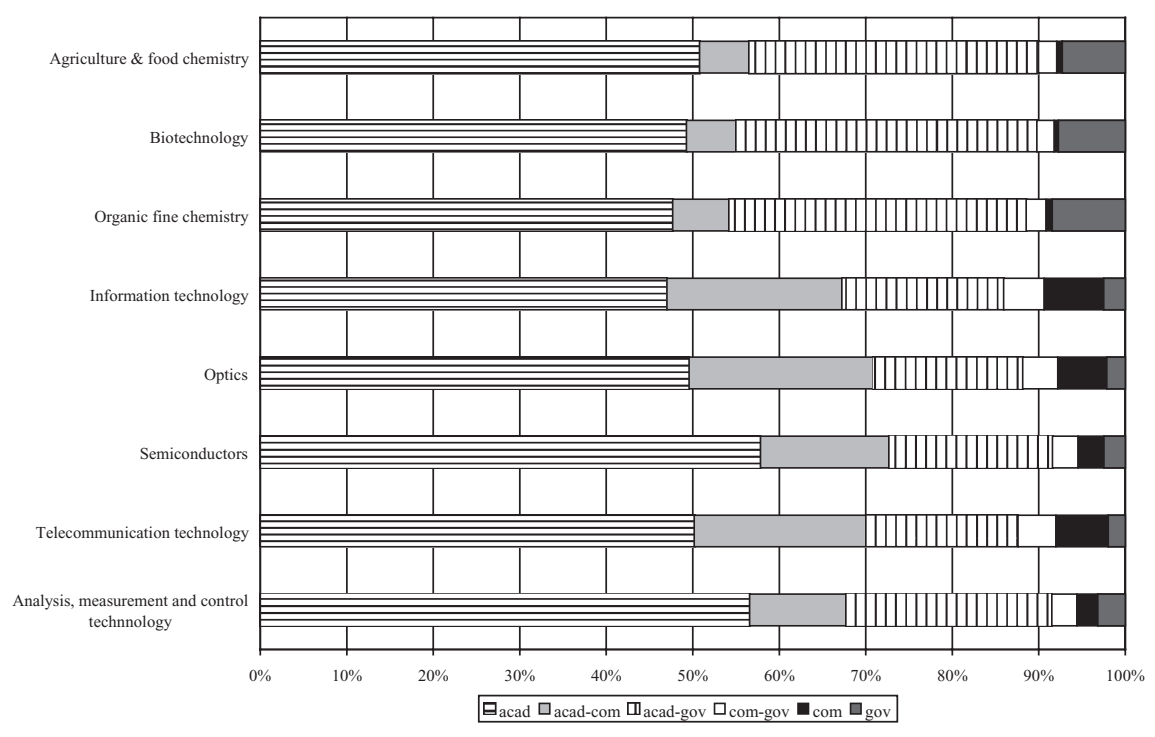

Fig. 10. Share of different forms of collaboration in science per technology

be a university and therefore an academic organisation. Furthermore, the names of different governmental research institutes such as TNO in the Netherlands and academic organisations such as the academic hospitals were included in the algorithm. This algorithm was then tested and improved several times on a changing subset of 2000 collaborations until more than $99 \%$ of the organisations were assigned correctly to one of the three types of organisations.

Figure 10 shows the share of the various forms of collaboration. Academic organisations are abbreviated as 'acad', companies as 'com' and governmental and non-profit-making organisations as 'gov'. Not surprisingly, collaboration between academic organisations is the most important form of collaboration in science. Collaboration between governmental organisations and academic organisations however, as well as between companies and academic organisations also frequently occurs. The share of collaborations between companies and between companies and governmental organisations is low. This is not because collaboration in fundamental research does not occur. On the contrary, this is a common phenomenon in science-industries (see for example Powell et al. 1996 for life sciences; and Stuart 2000 for high-technology industries). It is merely that it seldom leads to co-publication. It should be noted that there are differences between life sciences and physical sciences. Collaboration between companies and academic organisations is considerably more important in physical sciences, whereas collaboration between academic organisations and governmental organisations seems to be more important within the field of life sciences. The latter can be related to the importance of organisations such as hospitals and governmental health institutes in life-sciences research (Owen-Smith et al. 2002). In agricultural research, large governmental research institutes also traditionally play an 
important role in scientific knowledge production. With this distinction between different forms of collaborations, we can analyse whether the spatial patterns of collaboration between organisations with a different institutional background are different from those between organisations with a similar one.

\section{Geographical proximity and scientific collaboration}

To test the hypothesis that spatial collaboration between academic organisations and non-academic organisations (companies or governmental organisations) is more regionalised than collaboration between academic organisations, two different approaches are used. The first approach analyses whether different forms of collaborations take place over different distances. The second approach analyses the extent to which the possible differences in distances between different forms of collaborations are a result of the spatial distribution the various organisations across the Netherlands, or whether that geographical distance in itself is truly more important for some forms of collaborations.

In order to test the existence of variations in distance between different forms of collaboration the distance is modelled as a function of the type of collaboration. Different types of collaboration are specified by dummy variables. Two different models are estimated for each technology: model 1 distinguishes between homogenous collaborations (between the same types of organisations) and heterogeneous collaborations (between different types of organisations) and model 2 distinguishes between the six different types of collaborations. Using a logarithmic transformation for the dependent variable a tobit or censored model can be applied since distance is censored to the left at zero and to the right since the maximum is bounded by the country area. The distance of collaboration is measured by the travel time ${ }^{2}$ between the regions where the collaborating organisations are located.

Table 3 shows the results. Within this table the results of the life-sciences technologies are first presented together with those of the analysis, measurement and control technology. In the second part the four physical science based technologies are presented. In the first model the dummy variable takes value one if the collaborations are between the same types of organisations. In all technologies this variable has a significant and positive relation with distance. These outcomes suggest that homogenous collaborations take place over longer distances than heterogeneous collaborations.

In order to analyse possible differences in distance between various types of relations the second model includes dummy variables for the different types of relations. Academic collaboration is the reference dummy and as a result the other variables should be interpreted in comparison with this type of collaboration. The hypothesis is that collaborations between organisations with a different institutional background take place over a smaller geographical distance. Thus, the

${ }^{2}$ The average travel time between and within functional regions is based on a study of the OVG 2003 research of Statistics Netherlands (CBS) where the average travel time is estimated by a weighted average of private and public transport time. 
Table 3. Censored regressions of distance of collaborations

\begin{tabular}{|c|c|c|c|c|c|c|c|c|}
\hline \multirow[b]{2}{*}{ Constant } & \multicolumn{2}{|c|}{$\begin{array}{l}\text { Agriculture \& } \\
\text { food chemistry }\end{array}$} & \multicolumn{2}{|c|}{ Biotechnology } & \multicolumn{2}{|c|}{$\begin{array}{l}\text { Organic Fine } \\
\text { Chemistry }\end{array}$} & \multicolumn{2}{|c|}{$\begin{array}{l}\text { Analysis, } \\
\text { Measurement } \\
\text { \& Control } \\
\text { technology }\end{array}$} \\
\hline & $\begin{array}{l}3.791 * * \\
(0.010)\end{array}$ & $\begin{array}{l}4.043^{* * *} \\
(0.011)\end{array}$ & $\begin{array}{l}3.733 * * \\
(0.009)\end{array}$ & $\begin{array}{l}4.026^{* * *} \\
(0.010)\end{array}$ & $\begin{array}{l}3.788^{* * *} \\
(0.009)\end{array}$ & $\begin{array}{l}4.011 * * \\
(0.010)\end{array}$ & $\begin{array}{l}3.814 * * \\
(0.015)\end{array}$ & $\begin{array}{l}4.027 * * \\
(0.015)\end{array}$ \\
\hline $\begin{array}{l}\text { Dummy } \\
\text { homogenous }\end{array}$ & $\begin{array}{l}0.213^{* *} \\
(0.015)\end{array}$ & - & $\begin{array}{l}0.241 * * \\
(0.013)\end{array}$ & - & $\begin{array}{l}0.181 * * \\
(0.012)\end{array}$ & & $\begin{array}{l}0.166^{* * *} \\
(0.021)\end{array}$ & - \\
\hline Dummy acad & & Ref. & & Ref. & & Ref. & & Ref. \\
\hline Dummy comp & & $\begin{array}{c}-0.096 \\
(0.101)\end{array}$ & & $\begin{array}{c}-0.072 \\
(0.101)\end{array}$ & & $\begin{array}{c}-0.176 * * \\
(0.080)\end{array}$ & & $\begin{array}{c}-0.332 * * \\
(0.064)\end{array}$ \\
\hline Dummy gov & & $\begin{array}{l}-0.291^{* *} \\
(0.026)\end{array}$ & & $\begin{array}{c}-0.276^{* *} \\
(0.024)\end{array}$ & & $\begin{array}{c}-0.227 * * \\
(0.021)\end{array}$ & & $\begin{array}{c}-0.457 * * \\
(0.053)\end{array}$ \\
\hline $\begin{array}{l}\text { Dummy } \\
\text { acadcomp }\end{array}$ & & $\begin{array}{c}0.038 \\
(0.029)\end{array}$ & & $\begin{array}{c}0.000 \\
(0.027)\end{array}$ & & $\begin{array}{l}0.104 * * \\
(0.025)\end{array}$ & & $\begin{array}{c}0.040 \\
(0.029)\end{array}$ \\
\hline $\begin{array}{l}\text { Dummy } \\
\text { acadgov }\end{array}$ & & $\begin{array}{l}-0.310^{* *} \\
(0.016)\end{array}$ & & $\begin{array}{c}-0.349 * * \\
(0.014)\end{array}$ & & $\begin{array}{c}-0.283 * * \\
(0.014)\end{array}$ & & $\begin{array}{c}-0.393 * * \\
(0.025)\end{array}$ \\
\hline $\begin{array}{l}\text { Dummy } \\
\text { govcomp }\end{array}$ & & $\begin{array}{c}0.019 \\
(0.049)\end{array}$ & & $\begin{array}{c}-0.070 \\
(0.050)\end{array}$ & & $\begin{array}{c}-0.035 \\
(0.048)\end{array}$ & & $\begin{array}{l}0.117 * \\
(0.065)\end{array}$ \\
\hline $\begin{array}{l}\text { McKelvey and } \\
\text { Zavoina's } \mathrm{R}^{2}\end{array}$ & 0.13 & 0.13 & 0.017 & & 0.009 & 0.024 & 0.008 & 0.043 \\
\hline \multirow[t]{2}{*}{$\mathrm{N}$} & 15,949 & 15,949 & 19,719 & 19,719 & 22,194 & 22,194 & 8,160 & 8,160 \\
\hline & \multicolumn{2}{|c|}{$\begin{array}{l}\text { Information } \\
\text { technology }\end{array}$} & \multicolumn{2}{|c|}{ Optics } & \multicolumn{2}{|c|}{ Semiconductors } & \multicolumn{2}{|c|}{ Telecommunications } \\
\hline Constant & $\begin{array}{l}3.956 * * \\
(0.043)\end{array}$ & $\begin{array}{l}4.183^{* * *} \\
(0.033)\end{array}$ & $\begin{array}{l}4.076 * * \\
(0.025)\end{array}$ & $\begin{array}{l}4.478 * * \\
(0.031)\end{array}$ & $\begin{array}{l}4.132 * * \\
(0.026)\end{array}$ & $\begin{array}{l}4.352 * * \\
(0.028)\end{array}$ & $\begin{array}{l}4.006 * * \\
(0.028)\end{array}$ & $\begin{array}{l}4.332 * * \\
(0.032)\end{array}$ \\
\hline $\begin{array}{l}\text { Dummy } \\
\text { homogenous }\end{array}$ & $\begin{array}{l}0.147 * * \\
(0.043)\end{array}$ & - & $\begin{array}{l}0.235 * * \\
(0.038)\end{array}$ & & $\begin{array}{l}0.130^{* * *} \\
(0.038)\end{array}$ & - & $\begin{array}{l}0.212 * * \\
(0.041)\end{array}$ & \\
\hline Dummy acad & & Ref. & & Ref. & & Ref. & & Ref. \\
\hline Dummy comp & & $\begin{array}{c}-0.603 * * \\
(0.098)\end{array}$ & & $\begin{array}{c}-0.819^{* *} \\
(0.077)\end{array}$ & & $\begin{array}{c}-0.853^{* *} \\
(0.098)\end{array}$ & & $\begin{array}{c}-0.732 * * \\
(0.088)\end{array}$ \\
\hline Dummy gov & & $\begin{array}{l}-0.458 * * \\
(0.142)\end{array}$ & & $\begin{array}{l}-0.639 * * \\
(0.111)\end{array}$ & & $\begin{array}{c}-0.661 * * \\
(0.113)\end{array}$ & & $\begin{array}{c}-0.562 * * \\
(0.132)\end{array}$ \\
\hline $\begin{array}{l}\text { Dummy } \\
\text { acadcomp }\end{array}$ & & $\begin{array}{c}-0.167 * * \\
(0.052)\end{array}$ & & $\begin{array}{c}-0.208^{* *} \\
(0.043)\end{array}$ & & $\begin{array}{c}0.006 \\
(0.044)\end{array}$ & & $\begin{array}{c}-0.214 * * \\
(0.047)\end{array}$ \\
\hline $\begin{array}{l}\text { Dummy } \\
\text { acadgov }\end{array}$ & & $\begin{array}{l}-0.330 * * \\
(0.058)\end{array}$ & & $\begin{array}{l}-0.821^{* *} \\
(0.053)\end{array}$ & & $\begin{array}{l}-0.532 * * \\
(0.050)\end{array}$ & & $\begin{array}{c}-0.583 * * \\
(0.058)\end{array}$ \\
\hline $\begin{array}{l}\text { Dummy } \\
\text { govcomp }\end{array}$ & & $\begin{array}{c}-0.021 \\
(0.122)\end{array}$ & & $\begin{array}{c}-0.329 * * \\
(0.031)\end{array}$ & & $\begin{array}{c}-0.133 \\
(0.101)\end{array}$ & & $\begin{array}{c}-0.086 \\
(0.107)\end{array}$ \\
\hline $\begin{array}{l}\text { McKelvey and } \\
\text { Zavoina's } \mathrm{R}^{2}\end{array}$ & 0.01 & 0.031 & 0.013 & 0.098 & 0.004 & 0.071 & 0.011 & 0.057 \\
\hline $\mathrm{N}$ & 2,070 & 2,070 & 2,939 & 2,939 & 2,788 & 2,788 & 2,530 & 2,530 \\
\hline
\end{tabular}

Note: Significance levels: ** $0.95, * 0.90$. Standard errors in parentheses.

expectation holds that the dummy variables for academic-company, academicgovernmental and company-governmental collaborations have a significant negative effect.

In all eight technologies academic-governmental collaborations have a significantly lower travel time, indicating that geographical proximity is more important 
than in the case of academic collaborations. In the case of academic-company collaboration the results differ. In the case of life sciences there are no significant differences between academic collaborations and academic-company collaborations in travel time and in the case of organic fine chemistry academic-company collaborations have a significantly higher travel time, which is rather unexpected. A possible explanation could be that the national level is the most relevant level for academic-company collaboration and the international level for academic collaboration. In the case of the physical sciences, academic-company collaborations have as significant lower travel time than academic collaboration in three of the four technologies, which is in line with the hypothesis. No significant differences in travel time can be found between academic and academic-company collaboration in the case of semiconductors. Governmental-company collaborations sometimes have a significantly lower travel time across different technologies but this form of collaboration does not frequently occur.

Taking these outcomes together suggests that geographical proximity is more important for collaborations with different institutional backgrounds than for collaborations with organisations with the same institutional background. One has however, to be careful when interpreting this as strong evidence for the hypothesis, as geographical proximity seems to be less relevant for academic-company collaboration than is often assumed.

\section{Geographical proximity and scientific collaboration: A spatial interaction approach}

Alternatively, one can analyse whether geographical proximity between two organisations affects the probability of collaboration. To formally test whether geographical proximity is more important for collaborations of institutionally different actors than for similar ones, we apply a gravity model approach. The gravity-model is a well-known and often used spatial interaction model which predicts or analyses the interaction between two places (see for example Maggioni and Uberti 2007; or Dalgin et al. 2004 for recent applications).

The gravity model is described by the following formula:

$$
I_{i j}=K \frac{M_{i}^{\alpha_{1}} * M_{j}^{\alpha_{2}}}{d_{i j}^{\beta}}
$$

In this context $I$ stands for the intensity of collaboration (measured in numbers of collaboration) between regions $j, M$ for the total number of collaborations with at least one organisation in region $i$ or $j$ and $d$ for the functional distance (measured in average travel time) between region $i$ and $j . K$ is a constant. Because the interaction $I$ is based on collaboration (which has no direction) between regions, the distinction between the mass $M$ of regions $i$ and $j$ is not applicable and therefore $\alpha_{1}=\alpha_{2}$. This formula can be rewritten into the following regression model: 


$$
\operatorname{Ln}\left(I_{i j}\right)=K+\alpha \operatorname{Ln}\left(M_{i} M_{j}\right)+\beta \operatorname{Ln}\left(d_{i j}\right)+\varepsilon
$$

To the original equation (1), a logarithmic transformation of both the dependent and the independent variables is applied. This also adjusts for a possible nonnormal distribution of the variables, but in the case of the independent variable, this provides only a partial solution to the problem of non-normality. Alternatively, spatial interaction data could also be treated as count data, whereas in this case the intensity of interaction is expressed by the number of collaborations between two regions.

Due to the characteristics of count data, linear regression models are generally not appropriate since many of the assumptions such as normal distribution are not satisfied (Long 1997). Most often, a Poisson regression is applied, which is estimated using maximum likelihood techniques. In this case the observed intensity of collaboration between regions $i$ and $j$ has as Poisson distribution with a conditional mean $(\mu)$. This conditional mean is a function of the independent variables, which is specified in equation 3 :

$$
\operatorname{Pr}\left[I_{i j}\right]=\frac{\exp \left(-\mu_{i j}\right) \mu_{i j}^{I_{i j}}}{I_{i j} !} \text {, where } \mu_{i j}=\exp \left(K+\alpha \operatorname{Ln}\left(M_{i} M_{j}\right)+\beta \operatorname{Ln}\left(d_{i j}\right)\right.
$$

However, the amount of zeros in the dependent variable (indicating that there are many regions without any collaboration between them) is larger than assumed for a Poisson distribution and as a result the conditional variance is larger than the conditional mean. In order to allow for this overdispersion a negative binominal specification is used where an extra parameter $\alpha$ is introduced (see also Long 1997).

Table 4 shows the results. Due to the low number of observations of other forms of collaboration only those collaborations with at least one academic organisation are included. Within this table the results for the life sciences are presented first, the results for the physical sciences second and the results for analysis, measurement and control technology last. The coefficient of mass in all technologies for all forms of collaborations is both significant and positive, which seems to be a logical outcome. We are especially interested in possible differences in the coefficients of travel time on the intensity of collaboration indicating possible differences in the effect of geographical proximity on collaboration. For the aggregated number of collaborations the coefficient for travel time has a negative sign and is significant for all technologies. This seems to suggest that distance still matters for collaboration in science, a finding that is line with the findings of Katz (1994) and Liang and Zhu (2002).

Within life sciences travel time has a significant and negative effect on the intensity of collaboration for all the three distinguished forms of collaboration. The coefficient for travel time is higher for collaboration between academic and governmental organisations than for academic collaboration and collaboration between companies and academics. These differences are however, relatively 
Table 4. Results of the negative binominal gravity model regression

\begin{tabular}{|c|c|c|c|c|c|c|c|}
\hline Life sciences & Mass & Traveltime & Constant & $\mathrm{N}$ & $\begin{array}{c}\text { Number of } \\
\text { collaborations }\end{array}$ & $\begin{array}{c}\text { Pseudo } \\
\mathrm{R}^{2}\end{array}$ & $\begin{array}{c}\text { Log } \\
\text { likelihood }\end{array}$ \\
\hline \multicolumn{8}{|c|}{ Agriculture \& foodchemistry } \\
\hline Total & $\begin{array}{l}0.857 * * * \\
(0.018)\end{array}$ & $\begin{array}{l}-0.008 * * * \\
(0.001)\end{array}$ & $\begin{array}{l}-7.647 * * * \\
(0.186)\end{array}$ & 1,521 & 15,949 & 0.2970 & $-2,481.06$ \\
\hline Acad & $\begin{array}{l}0.937 * * * \\
(0.030)\end{array}$ & $\begin{array}{l}-0.003 * * * \\
(0.001)\end{array}$ & $\begin{array}{c}-8.363 * * * \\
(0.328)\end{array}$ & 324 & 6,763 & 0.2840 & -713.76 \\
\hline acad-com & $\begin{array}{l}0.957 * * * \\
(0.039)\end{array}$ & $\begin{array}{l}-0.004 * * * \\
(0.001)\end{array}$ & $\begin{array}{l}-7.032 * * * \\
(0.308)\end{array}$ & 1,024 & 1,175 & 0.3260 & -833.6 \\
\hline acad-gov & $\begin{array}{l}0.955^{* * * *} \\
(0.028)\end{array}$ & $\begin{array}{l}-0.007 * * * \\
(0.001)\end{array}$ & $\begin{array}{l}-8.177 * * * \\
(0.274)\end{array}$ & 1,444 & 6,106 & 0.3120 & $-1,681.04$ \\
\hline \multicolumn{8}{|l|}{ Biotechnology } \\
\hline Total & $\begin{array}{l}0.851 * * * \\
(0.018)\end{array}$ & $\begin{array}{l}-0.009 * * * \\
(0.001)\end{array}$ & $\begin{array}{l}-7.616 * * * \\
(0.184)\end{array}$ & 1,521 & 19,719 & 0.2924 & $-2,598.28$ \\
\hline Acad & $\begin{array}{l}0.912 * * * \\
(0.028)\end{array}$ & $\begin{array}{l}-0.004 * * * \\
(0.001)\end{array}$ & $\begin{array}{l}-8.122 * * * \\
(0.308)\end{array}$ & 324 & 8,222 & 0.2985 & -713.9 \\
\hline acad-com & $\begin{array}{l}0.956 * * * \\
(0.041)\end{array}$ & $\begin{array}{l}-0.005 * * * \\
(0.001)\end{array}$ & $\begin{array}{l}-6.940 * * * \\
(0.323)\end{array}$ & 1,024 & 1,296 & 0.3093 & -895.36 \\
\hline acad-gov & $\begin{array}{l}0.942 * * * \\
(0.027)\end{array}$ & $\begin{array}{l}-0.006 * * * \\
(0.001)\end{array}$ & $\begin{array}{c}-8.258 * * * \\
(0.268)\end{array}$ & 1,444 & 7,931 & 0.3010 & $-1,784.66$ \\
\hline \multicolumn{8}{|c|}{ Organic fine chemistry } \\
\hline Total & $\begin{array}{l}0.827 * * * \\
(0.017)\end{array}$ & $\begin{array}{l}-0.008 * * * \\
(0.001)\end{array}$ & $\begin{array}{l}-7.417 * * * \\
(0.175)\end{array}$ & 1,600 & 22,194 & 0.2834 & $-2,989.88$ \\
\hline Acad & $\begin{array}{l}0.943 * * * \\
(0.025)\end{array}$ & $\begin{array}{l}-0.004 * * * \\
(0.001)\end{array}$ & $\begin{array}{c}-8.642 * * * \\
(0.281)\end{array}$ & 400 & 8,720 & 0.3353 & -700.48 \\
\hline acad-com & $\begin{array}{l}1.017 * * * \\
(0.043)\end{array}$ & $\begin{array}{l}-0.005 * * * \\
(0.001)\end{array}$ & $\begin{array}{c}-7.663 * * * \\
(0.334)\end{array}$ & 1,089 & 1,591 & 0.2880 & $-1,034.85$ \\
\hline acad-gov & $\begin{array}{l}0.975 * * * \\
(0.028)\end{array}$ & $\begin{array}{l}-0.006^{* * * *} \\
(0.001)\end{array}$ & $\begin{array}{l}-8.769 * * * \\
(0.281)\end{array}$ & 1,600 & 8,908 & 0.2914 & $-1,957.25$ \\
\hline $\begin{array}{l}\text { Physical } \\
\text { sciences }\end{array}$ & Mass & Traveltime & Constant & $\mathrm{N}$ & $\begin{array}{c}\text { Number of } \\
\text { collaborations }\end{array}$ & $\begin{array}{c}\text { Pseudo } \\
\mathrm{R}^{2}\end{array}$ & $\begin{array}{c}\text { Log } \\
\text { likelihood }\end{array}$ \\
\hline \multicolumn{8}{|c|}{ Information-technology } \\
\hline Total & $\begin{array}{l}0.927 * * * \\
(0.034)\end{array}$ & $\begin{array}{l}-0.006 * * * \\
(0.001)\end{array}$ & $\begin{array}{l}-7.047 * * * \\
(0.289)\end{array}$ & 1,089 & 2,070 & 0.3118 & -991.23 \\
\hline Acad & $\begin{array}{l}0.953 * * * \\
(0.066)\end{array}$ & $\begin{array}{c}-0.002 * \\
(0.001)\end{array}$ & $\begin{array}{c}-6.838 * * * \\
(0.516)\end{array}$ & 289 & 873 & 0.2459 & -481.66 \\
\hline acad-com & $\begin{array}{l}0.927 * * * \\
(0.049)\end{array}$ & $\begin{array}{l}-0.006 * * * \\
(0.001)\end{array}$ & $\begin{array}{l}-5.874 * * * \\
(0.343)\end{array}$ & 784 & 554 & 0.3721 & -434.24 \\
\hline acad-gov & $\begin{array}{l}0.894 * * * \\
(0.071)\end{array}$ & $\begin{array}{l}-0.006 * * * \\
(0.001)\end{array}$ & $\begin{array}{l}-5.381 * * * \\
(0.448)\end{array}$ & 441 & 417 & 0.2416 & -494.71 \\
\hline \multicolumn{8}{|l|}{ Optics } \\
\hline Total & $\begin{array}{l}0.955^{* * *} \\
(0.030)\end{array}$ & $\begin{array}{l}-0.003 * * * \\
(0.001)\end{array}$ & $\begin{array}{l}-7.890 * * * \\
(0.271)\end{array}$ & 1,024 & 2,939 & 0.3219 & $-1,076.16$ \\
\hline Acad & $\begin{array}{l}1.043 * * * \\
(0.061)\end{array}$ & $\begin{array}{c}-0.000 \\
(0.001)\end{array}$ & $\begin{array}{l}-8.124 * * * \\
(0.501)\end{array}$ & 225 & 1,004 & 0.2557 & -447.97 \\
\hline acad-com & $\begin{array}{l}0.935 * * * \\
(0.046)\end{array}$ & $\begin{array}{c}-0.002 \\
(0.001)\end{array}$ & $\begin{array}{l}-6.831 * * * \\
(0.335)\end{array}$ & 900 & 1,025 & 0.3254 & -667.01 \\
\hline acad-gov & $\begin{array}{l}0.881 * * * \\
(0.065)\end{array}$ & $\begin{array}{c}-0.005 * * * \\
(0.001)\end{array}$ & $\begin{array}{c}-5.517 * * * \\
(0.445)\end{array}$ & 361 & 517 & 0.2895 & -411.03 \\
\hline
\end{tabular}


Table 4. Continued

\begin{tabular}{|c|c|c|c|c|c|c|c|}
\hline $\begin{array}{l}\text { Physical } \\
\text { sciences }\end{array}$ & Mass & Traveltime & Constant & $\mathrm{N}$ & $\begin{array}{c}\text { Number of } \\
\text { collaborations }\end{array}$ & $\begin{array}{c}\text { Pseudo } \\
\mathrm{R}^{2}\end{array}$ & $\begin{array}{c}\text { Log } \\
\text { likelihood }\end{array}$ \\
\hline \multicolumn{8}{|c|}{ Semiconductor-technology } \\
\hline Total & $\begin{array}{l}0.954 * * * \\
(0.033)\end{array}$ & $\begin{array}{l}-0.005 * * * \\
(0.001)\end{array}$ & $\begin{array}{l}-7.612 * * * \\
(0.291)\end{array}$ & 784 & 2,788 & 0.3522 & -815.79 \\
\hline Acad & $\begin{array}{l}0.974 * * * \\
(0.057)\end{array}$ & $\begin{array}{c}-0.001 \\
(0.001)\end{array}$ & $\begin{array}{c}-7.477 * * * \\
(0.475)\end{array}$ & 196 & 1,179 & 0.3096 & -377.47 \\
\hline acad-com & $\begin{array}{l}0.902 * * * \\
(0.060)\end{array}$ & $\begin{array}{l}-0.004 * * \\
(0.020)\end{array}$ & $\begin{array}{l}-6.113 * * * \\
(0.398)\end{array}$ & 529 & 783 & 0.2695 & -480.78 \\
\hline acad-gov & $\begin{array}{l}0.882 * * * \\
(0.077)\end{array}$ & $\begin{array}{l}-0.005 * * * \\
(0.001)\end{array}$ & $\begin{array}{l}-5.487 * * * \\
(0.504)\end{array}$ & 324 & 544 & 0.2605 & -413.58 \\
\hline \multicolumn{8}{|c|}{ Telecommunication-technology } \\
\hline Total & $\begin{array}{l}0.964 * * * \\
(0.032)\end{array}$ & $\begin{array}{l}-0.004 * * * \\
(0.001)\end{array}$ & $\begin{array}{l}-7.722 * * * \\
(0.278)\end{array}$ & 1,089 & 2,530 & 0.3435 & -975.47 \\
\hline Acad & $\begin{array}{l}0.989 * * * \\
(0.060)\end{array}$ & $\begin{array}{c}-0.002 * \\
(0.001)\end{array}$ & $\begin{array}{l}-7.326 * * * \\
(0.469)\end{array}$ & 289 & 968 & 0.2668 & -488.21 \\
\hline acad-com & $\begin{array}{l}0.960 * * * \\
(0.049)\end{array}$ & $\begin{array}{l}-0.004 * * * \\
(0.001)\end{array}$ & $\begin{array}{l}-6.611 * * * \\
(0.363)\end{array}$ & 784 & 830 & 0.3544 & -497.37 \\
\hline acad-gov & $\begin{array}{l}0.908 * * * \\
(0.063)\end{array}$ & $\begin{array}{l}-0.004 * * * \\
(0.001)\end{array}$ & $\begin{array}{l}-5.688 * * * \\
(0.410)\end{array}$ & 441 & 428 & 0.2788 & -456.64 \\
\hline \multicolumn{8}{|c|}{ Analysis, control \& measurement technology } \\
\hline Total & $\begin{array}{l}0.911 * * * \\
(0.022)\end{array}$ & $\begin{array}{l}-0.005 * * * \\
(0.001)\end{array}$ & $\begin{array}{l}-8.107 * * * \\
(0.224)\end{array}$ & 1,521 & 8,160 & 0.3319 & $-1,746.27$ \\
\hline Acad & $\begin{array}{l}0.914 * * * \\
(0.043)\end{array}$ & $\begin{array}{c}-0.002 * \\
(0.001)\end{array}$ & $\begin{array}{l}-7.695 * * * \\
(0.420)\end{array}$ & 289 & 3,650 & 0.2356 & -685.66 \\
\hline acad-com & $\begin{array}{l}0.932 * * * \\
(0.039)\end{array}$ & $\begin{array}{l}-0.006 * * * \\
(0.001)\end{array}$ & $\begin{array}{l}-6.736 * * * \\
(0.301)\end{array}$ & 1,089 & 1,452 & 0.3187 & -975.01 \\
\hline acad-gov & $\begin{array}{l}0.855^{* * *} \\
(0.033)\end{array}$ & $\begin{array}{l}-0.007 * * * \\
(0.001)\end{array}$ & $\begin{array}{l}-6.333 * * * \\
(0.289)\end{array}$ & 1,156 & 2,281 & 0.3396 & -958.93 \\
\hline
\end{tabular}

Note: Significance levels: $* * * 0.99, * * 0.95, * 0.90$. Standard errors in parentheses.

small. The higher coefficients for collaboration between academic and nonacademic organisations suggest that geographical proximity is more important for these forms of collaboration.

In the case of the physical science based technologies, travel time has no significant effect on the intensity of academic collaboration for semiconductors and optics. Within the field of information technology and telecommunication the coefficient is only significant at a significance level of $90 \%$. Neither in the field of optics does average travel time have a significant effect on the intensity of collaboration between firms and academic organisations, thereby indicating that geographical proximity is not important for university-industry collaborations either. There are no differences between the coefficient of travel time of academic-firm and academic-governmental collaboration in telecom and information technology, indicating that the effect of geographical proximity is more or less the same. The reason for the absence of travel time as a significant contributor to collaboration intensity may lie in the fact that physical science based technologies are more mature in 
nature, and firms in sectors that use these technologies have fewer opportunities to catch onto new market niches. Relationships between companies, academic organisations and governmental institutes are then more established, enhancing the institutional proximity based on trust and experience. This renders physical proximity less important in sectors that apply this technology.

The coefficient of travel time is also significant and almost the same in the case of collaboration between academic and governmental organisations and academic organisations and companies in the analysis, measurement and control technology. Average travel time has as a smaller effect for academic collaboration, indicating that here also, geographical proximity is less relevant for collaboration. ${ }^{3}$

These results suggest that geographical proximity is important for collaboration in research within the Netherlands and the importance varies between the form of collaboration and between life sciences and physical sciences. Within life sciences geographical proximity seems to be more significant for collaboration than within physical sciences and geographical proximity seems to matter more for collaboration between academic and non-academic organisations than for collaboration between academic organisations. These results therefore seem to confirm our main hypothesis that geographical proximity is more relevant for collaboration between organisations with different institutional background than for collaboration between organisations with the same institutional background.

\section{Conclusions}

In this study, we analysed the spatial characteristics of collaboration in scientific knowledge production in the Netherlands. Within science-based industries, collaboration between governmental, academic and private organisations in scientific knowledge production is an important and growing phenomenon. Based on theoretical insights from the literature of the geography of innovation it was hypothesised that geographical proximity is more important for collaboration between organisations with different institutional backgrounds. Using co-publications in scientific subfields that are relevant for technological innovation as a proxy for collaboration in research, this hypothesis was tested for eight science-based technologies in the life sciences and the physical sciences.

The main finding of this study is that geographical proximity is more relevant for collaboration between academic and non-academic organisations than for purely academic collaboration. This suggests that geographical proximity is indeed a way of overcoming the institutional differences between organisations, which is necessary for successful collaboration.

\footnotetext{
3 A residual analysis has been performed for all regressions and it showed that the most northern and most southern regions with a university (the region around Groningen and the region around Maastricht) collaborated over longer distances than predicted by the model. A closer look revealed that this was almost entirely dependent upon the universities that collaborated with other universities in the Netherlands, which again suggests that institutional proximity is more important than geographical proximity here. Results of the residual analysis are available on request.
} 
This study also shows however, that the importance of geographical proximity does not imply that the regional level is therefore the relevant spatial scale. The national level seems to be more significant for collaboration between companies and academic organisations than the regional level. For collaborations between academic and governmental organisations, the regional level seems to be relatively important. These findings suggest that the regional dimension of the innovation system in science-based industries in the Netherlands should not be overemphasised. Geographical proximity plays a significant, yet minor role for collaboration between academic organisations within the Netherlands, which is also evident from the high share of international collaborations. Therefore, geographical proximity especially seems to matter for collaboration in the case of institutional differences, thereby facilitating successful collaboration. These results fit into the recent proximity debate about the exact role and effect of geographical proximity for collaboration and knowledge exchange between organisations (Boschma 2005; Torre and Rallet 2005) and suggest that geographical proximity is more important in an indirect way by overcoming institutional differences than in directly stimulating interaction as it is often assumed.

\section{References}

Acs ZJ (2002) Innovation and the growth of cities. Edward Elgar, Cheltenham

Anselin L, Varga A, Acs Z (2000) Geographic and sectoral characteristics of academic knowledge externalities. Papers in Regional Science 79: 435-445

Audretsch DB, Feldman MP (1996) R\&D spillovers and the geography of innovation and production. American Economic Review 86: 630-640

Boschma R (2005) Proximity and innovation: A critical assessment. Regional Studies 39: 61-74

Breschi S, Lissoni F (2001) Knowledge spillovers and local innovation systems: A critical survey. Industrial and Corporate Change 10: 975-1005

Cockburn I, Henderson R (1998) Absorptive capacity, coauthoring behavior and the organisation of research in drug discovery. The Journal of Industrial Economics 46: 157-182

Canton E, Lanser D, Noailly J, Rensman M, Van de Ven J (2005) Crossing borders: When science meets industry. CPB Netherlands Bureau for Economic Policy Analysis, Den Haag

Cooke P, Uranga MG, Etxebarria G (1997) Regional innovation systems: Institutional and organisational dimensions. Research Policy 26: 475-491

Dalgin M, Mitra D, Trindade V (2004) Inequality, nonhomothetic preferences and trade: A gravity approach. NBER Working Paper Series 10800

Dasgupta P, David PA (1994) Toward a new economics of science. Research Policy 23: 487-521

DeSolla Price D (1984) The science/technology relationship, the craft of experimental science, and policy for the improvement of high technology innovation. Research Policy 13: 3-20

Etzkowitz H, Leydesdorff L (2000) The dynamics of innovation: From National Systems and "Mode 2" to a Triple Helix of university-industry-government relations. Research Policy 29: 109123

Feldman MP (1999) The new economics of innovation, spillovers and agglomeration: A review of empirical studies. Economics of Innovation and New Technology 8: 5-25

Frenken K, Van Oort FG (2004) The geography of research collaboration: Theoretical considerations and stylised facts in biotechnology in Europe and the United States. In: Cooke P, Piccaluga A (eds) Regional economies as knowledge laboratories. Edward Elgar, Cheltenham UK and Northampton MA

Gertler MS (2003) Tacit knowledge and the economic geography of context, or the indefinable tacitness of being (there). Journal of Economic Geography 3: 75-99 
Gittelman M, Kogut B (2003) Does good science lead to valuable knowledge? Biotechnology firms and the evolutionary logic of citation patterns. Management Science 49: 366-382

Glänzel W (2001) National characteristics in international scientific co-authorship relations. Scientometrics 51: 69-115

Goddard JG, Isabelle M (2006) How do public laboratories collaborate with industry? New survey evidence from France. Working Paper Series 2006/02 Imri, Université Paris Dauphine

Gordon MD (1980) A critical reassessment of inferred relations between multiple authorship, scientific collaboration, the production of papers and their acceptance for publication. Scientometrics 2: 193-210

Howells JRL (2002) Tacit knowledge, innovation and economic geography. Urban Studies 39: 871884

Jaffe AB, Trajtenberg M, Henderson R (1993) Geographic localization of knowledge spillovers as evidenced by patient citations. The Quarterly Journal of Economics 108(3): 577-598

Katz JS (1994) Geographical proximity and scientific collaboration. Scientometrics 31: 31-43

Katz JS, Martin BR (1997) What is research collaboration? Research Policy 26: 1-18

Long, JS (1997) Regression models for categorical and limited dependent variables. Sage, Thousand Oaks

Liang L, Zhu L (2002) Major factors affecting China's inter-regional research collaboration: Regional scientific productivity and geographical proximity. Scientometrics 55: 287-16

Luukkonen T, Persson O, Sivertsen G (1992) Understanding patterns of international scientific collaboration. Science, Technology, \& Human Values 17: 101-126

Luukkonen T, Tijssen RJW, Persson O, Sivertsen G (1993) The measurement of international scientific collaboration. Scientometrics 28: 15-36

Maggioni MA, Uberti TE (2007) Inter-regional knowledge flows in Europe: An econometric analysis. In: Frenken K (ed) Applied evolutionary economics and economic geography, Edward Elgar, Cheltenham, UK

Malmberg A, Maskell P (2002) The elusive concept of localization economies, toward a knowledgebased theory of spatial clustering. Environment and Planning A 34: 429-449

Owen-Smith J, Riccaboni M, Pamolli F, Powell WW (2002) A comparison of US and European university-industry relations in life-sciences. Management Science 48: 24-43

Pavitt K (1984) Sectoral patterns of technical change: Towards a taxonomy and a theory. Research Policy 13: 343-373

Powell WW, Koput K, Smith-Doerr L (1996) Interorganisational collaboration and the locus of innovation: Networks of learning in biotechnology. Administrative Science Quarterly 41: 116-145

Rosenberg N (1990) Why do firms do basic research (with their own money)? Research Policy 19: $165-174$

Stuart T (2000) Interorganisational alliances and the performance of firms: A study of growth and innovation rates in a high-technology industry. Administrative Science Quarterly 43: 668-698

Torre A, Rallet A (2005) Proximity and localization. Regional Studies 39: 47-59

Van Looy B, Zimmerman E, Veugelers R, Verbeek E, Mello J, Debackere K (2003) Do sciencetechnology interactions pay off when developing technology? Scientometrics 57: 355-367

Van Oort FG (2004) Urban growth and innovation: Spatially bounded externalities in the Netherlands. Ashgate, Aldershot

Varga A (1998) University research and regional innovation: A spatial econometric analysis. Kluwer Academic Publishers, Boston

Wagner C (2005) Six case studies of international collaboration in science. Scientometrics 62: 3-26

Wagner C, Leydesdorff L (2005) Mapping the network of global science comparing international co-authorships from 1990 to 2000. International Journal of Technology and Globalization 1: 185-208

Wagner-Doebler R (2001) Continuity and discontinuity of collaboration behaviour since 1800 from a bibliometric point of view. Scientometrics 52: 503-517 


\begin{abstract}
La colaboración y el intercambio de conocimiento son supuestamente más fáciles si hay una proximidad geográfica debido al carácter tácito del conocimiento. Varios investigadores han criticado recientemente esta suposición sobre la proximidad geográfica como simplista argumentando que el papel preciso que juega la proximidad geográfica en el intercambio de conocimiento y la colaboración aun no está claro. Este artículo analiza el rol de la proximidad geográfica en la investigación científica colaborativa en tecnologías de base científica entre universidades e institutos de investigación privados o gubernamentales. Analizamos la hipótesis de que la colaboración entre tipos diferentes de organizaciones es más localizada geográficamente que la colaboración entre organizaciones que son similares debido a su proximidad institucional. Usando datos sobre co-publicaciones, se analizan patrones de colaboración y se confirma la hipótesis.
\end{abstract}

Palabras clave: Colaboración, proximidad, conocimiento, colaboración universidad-industria.

要旨 : 知識には言葉で表現できない暗黙の性質があることから、知識の協力に関する共同研 究と交流は地理的近接性によってより容易になると考えられる。最近、多くの学者が地理的 近接性に関するこうした見解を単純化しすぎていると批判し、知識交換と協力における地理 的近接性の正確な役割は依然として不確かなままであると論じている。本論では、大学、企 業/政府系の研究機関間での科学技術分野の共同研究における地理的近接性の役割を分析する。 我々は、組織的な近接性のため、異なるタイプの研究機関同士の共同研究は類似の研究機関 同士の共同研究よりも地理的により局地化しているという仮説を検証した。共同出版データ を用いて協力パターンを分析した結果、この仮定は正しかったことが確認された。 